\title{
Studies on Japanese Mint (Mentha arvensis L.) and Maize (Zea mays L.) Intercropping System under Irrigated Condition
}

\author{
Suparna Nayak $^{1 *}$, Anand B. Mastiholi ${ }^{2}$, T. N. Pushpa ${ }^{1}$ and D. Srikantaprasad ${ }^{1}$ \\ ${ }^{1}$ Department of Plantation, Spices, Medicinal and Aromatic Crops, KRCCH, Arabhavi., \\ UHS, Bagalkot -587 104, Karnataka, India. \\ ${ }^{2}$ Regional Horticultural Research and Extension Center, Dharwad, UHS, \\ Bagalkot-587 104, Karnataka, India \\ *Corresponding author
}

\section{A B S T R A C T}

\begin{tabular}{l} 
Ke y w o r d s \\
Japanese mint, \\
Maize, \\
Intercropping, \\
Herbage yield, LER \\
\hline Article Info \\
\hline $\begin{array}{l}\text { Accepted: } \\
\text { 14 June } 2020 \\
\text { Available Online: } \\
\text { 10 July } 2020\end{array}$ \\
\hline
\end{tabular}

The field experiment to study the possibility of growing Japanese mint as intercrop with maize under irrigated condition was undertaken during kharif 2016-17. The experiment was laid out in randomized block design with three replications. There are eight treatments viz., $\mathrm{T}_{1}$ : Maize $(45 \mathrm{~cm} / 75 \mathrm{~cm} \mathrm{x} 20 \mathrm{~cm})+$ Japanese mint $(120 \mathrm{~cm} \mathrm{x} 15 \mathrm{~cm})(2: 1), \mathrm{T}_{2}$ : Maize $(45 \mathrm{~cm} / 75 \mathrm{~cm}$ x $20 \mathrm{~cm})+$ Japanese mint $(25 \mathrm{~cm} / 95 \mathrm{~cm}$ x $15 \mathrm{~cm})(2: 2), \mathrm{T}_{3}$ : Maize $(120 \mathrm{~cm} \times 10 \mathrm{~cm})+$ Japanese mint $(30 \mathrm{~cm} / 60 \mathrm{~cm} \mathrm{x} 15 \mathrm{~cm})(1: 3), \mathrm{T}_{4}$ : Maize $(90 \mathrm{~cm} \mathrm{x} 15$ $\mathrm{cm})+$ Japanese mint $(90 \mathrm{~cm} \times 15 \mathrm{~cm})(1: 1), \mathrm{T}_{5}$ : Maize $(90 \mathrm{~cm} \times 15 \mathrm{~cm})+$ Japanese mint $(30 \mathrm{~cm} / 60 \mathrm{~cm} \times 15 \mathrm{~cm})(1: 2), \mathrm{T}_{6}$ : Maize $(60 \mathrm{~cm} \times 20 \mathrm{~cm})+$ Japanese mint $(60 \mathrm{~cm} \mathrm{x} 15$ $\mathrm{cm})(1: 1), \mathrm{T}_{7}$ : Sole maize $(60 \mathrm{~cm} \times 20 \mathrm{~cm})$ and $\mathrm{T}_{8}$ : Sole Japanese mint $(45 \mathrm{~cm} \mathrm{x} 15 \mathrm{~cm})$. The treatment $\mathrm{T}_{3}$ recorded significantly higher LER (1.5), ATER (1.4), Japanese mint equivalent oil yield $(312.4 \mathrm{~kg} / \mathrm{ha})$ and maize grain equivalent yield $(252.5 \mathrm{q} / \mathrm{ha})$ with maximum B: C ratio (3.34) among the intercropping systems. However, dry matter production $(51.5 \mathrm{~g} / \mathrm{plant})$ and fresh herbage yield $(150.0 \mathrm{~g} / \mathrm{plant}$ and $20.5 \mathrm{t} / \mathrm{ha})$ was significantly higher in sole Japanese mint $\left(\mathrm{T}_{8}\right)$. The study showed that Japanes mint can be grown profitably with maize as intercrop in 1: 3 row proportion with adjustment in cropping geometry of maize.

\section{Introduction}

The purpose of intercropping is to produce higher yield on a given piece of land by making use of resources that would otherwise not be utilized by a single crop efficiently (Evans et al., 2001). With increase in the negative impact of climate change and global warming on the growth and yield of crops, intercropping could be a viable agronomic practice to minimize risk, increase income of farmers besides sustaining the yield. Crops in intercropping system suffer less from insect, disease, weed problems and also help to ameliorate soil fertility.

With dwindling resources, and ecological and socioeconomic issues confronting the farming 
community, there is need to go for different cropping system approach.

The present research programme is aimed to bring out optimum intercropping system involving maize and mint in irrigated area to get both essential oil yield and additional income to the farmers without compromising the maize production in traditional irrigated belt in Karnataka. This helps to overcome many ecological and socioeconomic problems of the small and marginal farmers.

Japanese mint (Mentha arvensis L.) is an important aromatic cash crop grown in India. It is commercially valuable because of its high oil yield and the menthol content. Leaves and stems are known to contain about 0.6 per cent oil which has 70-85 per cent menthol in it. This crop has medicinal uses and aromatic oil is used in many commercial industries. The cultivation of Japanese mint is mostly concentrated only in Tarai region of Uttar Pradesh extending to parts of Indo-Gangetic plains. But, the demand for mint oil and menthol is increasing every year. This necessitates introducing the crop in nontraditional areas so Japanese mint can be introduced in cropping systems with the existing crops without compromising the yield of main crop.

Maize is an important and popular cereal crop with the huge yield potential and it is grown as monocrop under irrigated condition. Monoculture of maize deprives the soil of its nutrients. Since, maize is relatively a widely spaced crop, inter-row space could profitably be utilized for growing other crops particularly in kharif season. Hence, the present study was undertaken to know the possibility of introducing Japanese mint as intercrop with the main crop maize by adjusting cropping geometry and with different row proportion of main and companion crop.

\section{Materials and Methods}

The present field study on intercropping of Japanese mint with maize was conducted during kharif, 2016 at the Horticultural Research and Extension Station, Hidkal Dam (under the University of Horticultural Sciences, Bagalkot), Tq. Hukkeri, Dist. Belagavi, Karnataka. The soil of experimental area was red sandy loam with depth varying from 0.5 to $1.5 \mathrm{~m}$. The treatment consisted of six treatments of mint and maize intercropping combination with different row proportion and cropping geometry and two sole crop treatment one each of Japanese mint and maize viz., $\mathrm{T}_{1}$ : Maize $(45 \mathrm{~cm} / 75 \mathrm{~cm} \mathrm{x} 20$ $\mathrm{cm})$ + Japanese Mint (120 cm x $15 \mathrm{~cm})(2: 1)$, $\mathrm{T}_{2}$ : Maize $(45 \mathrm{~cm} \mathrm{/} 75 \mathrm{~cm} \mathrm{x} 20 \mathrm{~cm})+$ Japanese Mint $(25 \mathrm{~cm} / 95 \mathrm{~cm}$ x $15 \mathrm{~cm})(2: 2)$, $\mathrm{T}_{3}$ : Maize $(120 \mathrm{~cm} \mathrm{x} 10 \mathrm{~cm})+$ Japanese Mint $(30 \mathrm{~cm} / 60 \mathrm{~cm} \times 15 \mathrm{~cm})(1: 3), \mathrm{T}_{4}$ : Maize $(90$ $\mathrm{cm}$ x $15 \mathrm{~cm})$ + Japanese Mint (90 cm x 15 $\mathrm{cm})$ (1:1), T5: Maize $(90 \mathrm{~cm} \times 15 \mathrm{~cm})+$ Japanese Mint (30 cm / $60 \mathrm{~cm}$ x $15 \mathrm{~cm})(1: 2)$, $\mathrm{T}_{6}$ : Maize $(60 \mathrm{~cm}$ x $20 \mathrm{~cm})+$ Japanese Mint $(60 \mathrm{~cm} \times 15 \mathrm{~cm})(1: 1), \mathrm{T}_{7}$ : Sole Maize $(60 \mathrm{~cm}$ x $20 \mathrm{~cm})$ andT $T_{8}$ : Sole Japanese Mint $(45 \mathrm{~cm}$ $\mathrm{x} 15 \mathrm{~cm})$. The varieties used were Kosi (Japanese mint) and Ganga kaveri (Maize). The design of the experiment was randomised block design and replicated thrice.

After the land was made into plots of $6 \mathrm{~m}$ x 6 $\mathrm{m}$ well decomposed FYM (10 t/ha) was applied 21 days before planting. The stolons of Japanese mint having 2 to 3 nodes per cuttings $(2-3 \mathrm{~cm})$ were used for planting and in case of maize; seeds were used for the sowing. Stolons were planted vertically in rows (2.5- $4.0 \mathrm{~cm}$ deep) according to different row combination treatments. Maize seeds were sown at 1 to $2 \mathrm{~cm}$ depth as per the spacing levels. Plant population of maize was kept constant in all the treatments by varying the row spacing and plant to plant spacing whereas, the plant population of Japanese 
mint varied in different treatments as per different row proportions and spacing.

Phosphorous and potassium fertilizers were applied at the rate of 50 and 40 kilo gram per hectare in the form of single super phosphate and muriate of potash respectively, to all the plots as a basal dose for Japanese mint. Top dressing of urea $(160 \mathrm{~kg} / \mathrm{ha})$ as a source of nitrogen was applied in three split doses at 30, 60 days after planting and after first harvest. For maize, 75: 75: 37.5 kilo gram of nitrogen, phosphorous and potash was applied as basal dose in the form of urea, di-ammonium phosphate and muriate of potash, respectively. After one month of maize sowing, remaining nitrogen of 75 kilo gram per hectare was supplied as top dressing in the form of urea.

Irrigations were given at eight to ten days intervals. Hand weeding was done at an interval of 15 days from planting till the complete crop growth period. The maize was harvested at 110 days after planting and Japanese mint was harvested at 120 days after planting. Mint harvesting was done in the early afternoon to get more percentage of oil in the leaves. Essential oil content was estimated at harvest by hydrodistillation method in the Clevenger's apparatus by adopting standard procedure. Menthol content was estimated by using gas chromatography and expressed in percentage.

\section{Results and Discussion}

\section{Growth parameters}

Wider spacing of maize $(120 \mathrm{~cm})$ with closer spacing of mint recorded the maximum plant height $(97.7 \mathrm{~cm})$ which was on par with other intercropping treatments (Table 1). The plant height of mint increased under intercropping with maize as a result of shading. The plants were tall, lean and lanky in all the intercropping treatments when compared to the sole cropping of Japanese mint. This was possibly due to competition for light between maize and Japanese mint plants in different cropping geometries. In contrast, sole crop Japanese mint plants were shorter $(64.1 \mathrm{~cm})$ compared to intercropped mint plants owing to absence of competition from maize and also due to better availability of water and nutrients. Intercropped Japanese mint had to compete with companion crop for water and nutrients in spite of their differences in root characteristics. The results of the studies conducted on mint species with sugarcane (Singh, 1998) are in line with the present investigation.

However, Japanese mint in intercropping situation recorded lowest number of branches (6.9), lower stem girth $(5.9 \mathrm{~mm})$ and lesser values for plant spread both in East -West $(46.6 \mathrm{~cm})$ and North - South $(43.6 \mathrm{~cm})$ direction compared to sole crop of Japanese mint which produced higher number of branches (14.3), more stem girth $(7.0 \mathrm{~mm}$ at) and more plant spread in both East -West $(55.4 \mathrm{~cm})$ and North - South $(54.7 \mathrm{~cm})$ directions (Table 1). It was mainly due to availability of abundant light, water, nutrients, lack of competition and space between the rows which encouraged horizontal growth of plants. The results are in conformity with the findings of Rajeshwara Rao, (2002) and Prakasa Rao et al., (1988) where rose scented geranium was intercropped with corn mint and java citronella, respectively.

The sole crop of Japanese mint recorded significantly maximum $\left(3971.7 \mathrm{~cm}^{2}\right)$ leaf area however, it was on par $\mathrm{T}_{3}\left(3580.1 \mathrm{~cm}^{2}\right)$. Except $\mathrm{T}_{3}$ other intercropping systems recorded significantly lower leaf area. This might be attributed to the increased leaf number, leaf size, the number of branches and also more canopy spread. The reduced leaf area in intercropping might be due to limited photosynthetic ability because of lower light 
interception on the surface of Japanese mint. Apart from shade, the nutrients and moisture shortage due to increased plant population appear to have resulted in reduced leaf area in intercropped Japanese mint. Similar findings were observed by Chandranath and Pujeri, (2011) in ashwagandha when intercropped with sunflower.

The Leaf area index (LAI) was found significantly highest (8.0) in 1:3 row proportion $\left(\mathrm{T}_{3}\right)$ when compared to all other treatments (Table 2). This was because of higher plant population in closer spacing. The leaf area ratio was found highest $\left(89.0 \mathrm{~cm}^{2} / \mathrm{g}\right)$ in sole cropping of Japanese mint however, it was on par with $T_{3}$ and $T_{5}$. It is mainly because of the maximum leaf area and dry matter accumulation in the above treatments. Similar observations were made by Chandranath and Pujeri, (2011) in ashwagandha when intercropped with sunflower.

\section{Yield parameters}

Japanese mint under intercropping system produced lower total dry matter production compared to sole crop of Japanese mint (51.5 $\mathrm{g} /$ plant) followed by $\mathrm{T}_{3}$ (40.6 g/plant) (Table $3)$. The reduction in total dry matter production in mint in intercropping system might be attributed to the lower dry matter producing ability caused due to reduced growth supporting factors like nutrients, moisture and light. Reduction in leaf area is another factor which is an important part of the plant that determines the photosynthetic ability, growth and further dry matter production. The results of Chandranath and Pujeri, (2011) where ashwagandha was intercropped with sunflower shows similar trend.

The sole cropping system of Japanese mint with row spacing of $45 \mathrm{~cm}\left(\mathrm{~T}_{8}\right)$ recorded significantly higher fresh herbage yield of 150.0 gram per plant, 41.3 kilo gram per plot and 20.5 ton per hectare (Table 3) and oil yield of 388.0 gram per plot and 192.4 kilo gram per hectare (Table 4). The sole crop had more plant population per unit area than intercropped mint and due to no competition for resources with maize. Whereas, intercropped Japanese mint suffered more than 50 per cent losses in biomass yield when compared with monocrop of Japanese mint owing to lesser plant density. Decrease in herbage yield lead to decrease in oil yield of plant. Findings of the present study are in line with the previous findings of spearmint intercropped with maize (Lulie et al., 2014).

\section{Oil and menthol content (\%)}

The maximum essential oil content $(0.9 \%)$ was observed both in sole cropping of Japanese mint $\left(\mathrm{T}_{8}\right)$ and in wider row spacing of maize $(120 \mathrm{~cm})$ with $30 \mathrm{~cm}$ row spacing of Japanese mint in 1:3 row proportion $\left(\mathrm{T}_{3}\right)$. However, the oil content (0.8) in $\mathrm{T}_{3}$ was also on par with the above treatments (Table 4). Sole crop and wider spacing of maize provided sufficient quantity of sunlight for the mint plants which lead to higher oil content. The lower oil content under intercropping system might be due to lower availability of resources particularly the light due to shading by tall maize crop and limited horizontal growth of mint which produced less number of branches and flowering tops. Flowering tops contain high oil content compared to other parts of the plant. Thus, lesser flowering tops and shady condition lead to significant changes in essential oil content. The results are in line with the findings of Lulie et al., (2014) where spear mint was intercropped with the maize. In contrast, menthol content in Japanese mint was not affected by different row proportions and intercropping systems (Table 4). Thus, maize crop has not influenced the quality of the essential oil. 
Table.1 Plant height, number of branches per plant, stem girth and canopy spread in Japanese mint as influenced by intercropping with maize

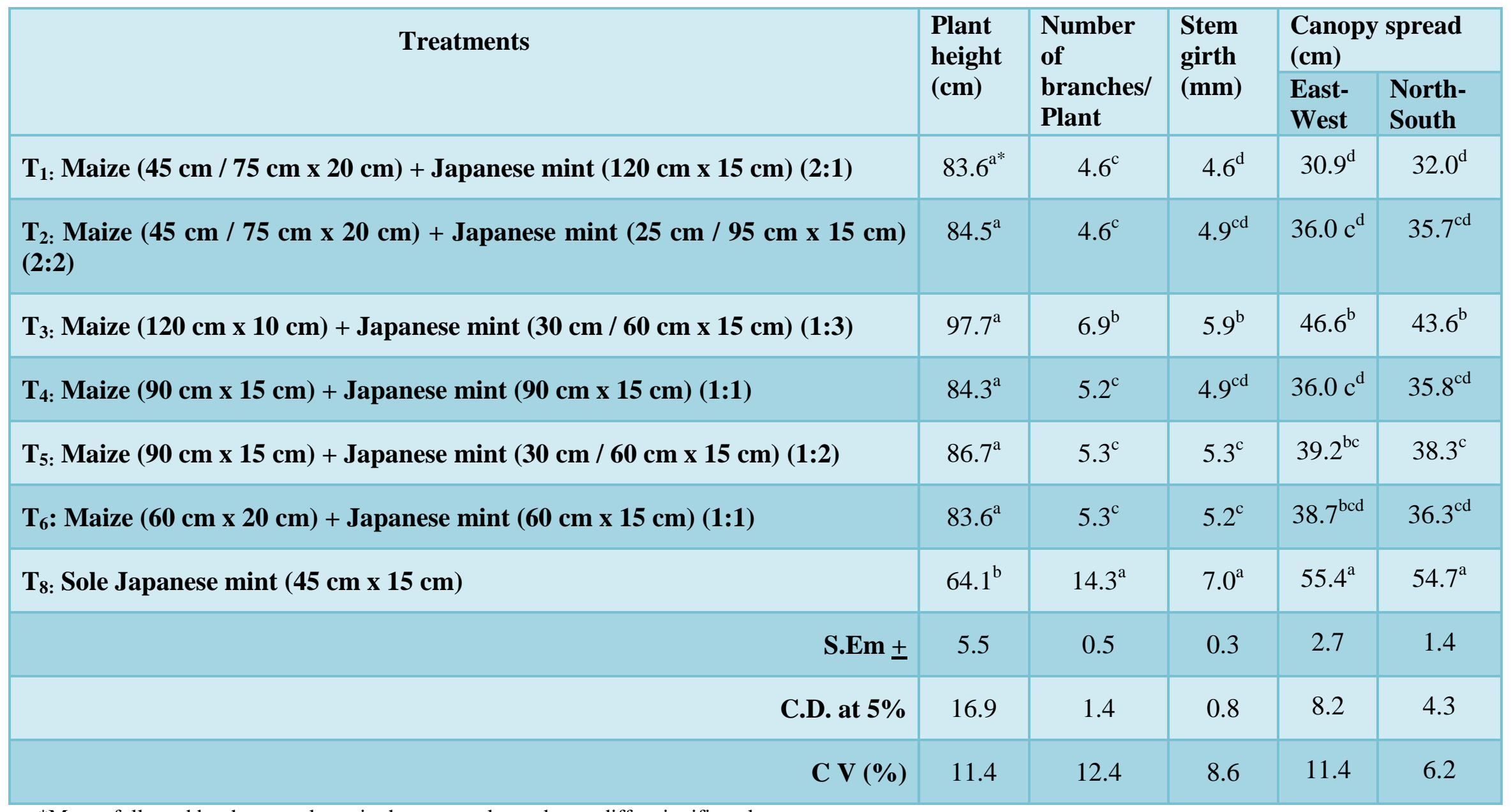

*Means followed by the same letter in the same column do not differ significantly.

Note: $\mathrm{T}_{7}$ : Sole maize $(60 \mathrm{~cm}$ x $20 \mathrm{~cm})$ 
Table. 2 Leaf area, leaf area index and leaf area ratio in Japanese mint as influenced by intercropping with maize

\begin{tabular}{|c|c|c|c|}
\hline Treatments & $\begin{array}{c}\text { Leaf area } \\
\left(\mathrm{cm}^{2}\right)\end{array}$ & $\begin{array}{l}\text { Leaf area } \\
\text { index }\end{array}$ & $\begin{array}{l}\text { Leaf area ratio } \\
\qquad\left(\mathrm{cm}^{2} / \mathrm{g}\right)\end{array}$ \\
\hline$T_{1:}$ Maize $(45 \mathrm{~cm} / 75 \mathrm{~cm}$ x $20 \mathrm{~cm})+$ Japanese mint $(120 \mathrm{~cm} \times 15 \mathrm{~cm})(2: 1)$ & $1038.4^{\mathrm{c}}$ & $0.6^{\mathrm{f}}$ & $60.2^{b}$ \\
\hline$T_{2:}$ Maize (45 cm / $75 \mathrm{~cm}$ x $\left.20 \mathrm{~cm}\right)+$ Japanese mint $(25 \mathrm{~cm} / 95 \mathrm{~cm}$ x $15 \mathrm{~cm})(2: 2)$ & $1309.2^{c}$ & $3.5^{\mathrm{d}}$ & $61.0^{\mathrm{b}}$ \\
\hline$T_{3:}$ Maize $(120 \mathrm{~cm} \times 10 \mathrm{~cm})$ + Japanese mint $(30 \mathrm{~cm} / 60 \mathrm{~cm} \times 15 \mathrm{~cm})(1: 3)$ & $3580.1^{\mathrm{a}}$ & $8.0^{\mathrm{a}}$ & $88.5^{\mathrm{a}}$ \\
\hline$T_{4:}$ Maize $(90 \mathrm{~cm} \times 15 \mathrm{~cm})$ + Japanese mint $(90 \mathrm{~cm}$ x $15 \mathrm{~cm})(1: 1)$ & $1413.9^{c}$ & $1.0^{\text {ef }}$ & $66.5^{b}$ \\
\hline$T_{5:}$ Maize (90 cm x $\left.15 \mathrm{~cm}\right)$ + Japanese mint $(30 \mathrm{~cm} / 60 \mathrm{~cm}$ x $15 \mathrm{~cm})(1: 2)$ & $2048.3^{b}$ & $4.5^{\mathrm{c}}$ & $84.7^{\mathrm{a}}$ \\
\hline$T_{6}:$ Maize $(60 \mathrm{~cm} \times 20 \mathrm{~cm})+$ Japanese mint $(60 \mathrm{~cm} \times 15 \mathrm{~cm})(1: 1)$ & $1382.0^{\mathrm{c}}$ & $1.5^{\mathrm{e}}$ & $59.8^{\mathrm{b}}$ \\
\hline$T_{8:}$ Sole Japanese mint $(45 \mathrm{~cm} \mathrm{x} 15 \mathrm{~cm})$ & $3971.7^{\mathrm{a}}$ & $5.8^{b}$ & $89.0^{\mathrm{a}}$ \\
\hline S.Em \pm & 145.5 & 0.2 & 5.2 \\
\hline C.D. at $5 \%$ & 448.4 & 0.7 & 16.1 \\
\hline $\mathrm{CV}(\%)$ & 11.8 & 11.4 & 12.4 \\
\hline
\end{tabular}

*Means followed by the same letter in the same column do not differ significantly.

Note: $\mathrm{T}_{7}$ : Sole maize $(60 \mathrm{~cm} \times 20 \mathrm{~cm})$ 
Table.3 Total dry matter production and fresh herbage yield in Japanese mint as influenced by intercropping with maize

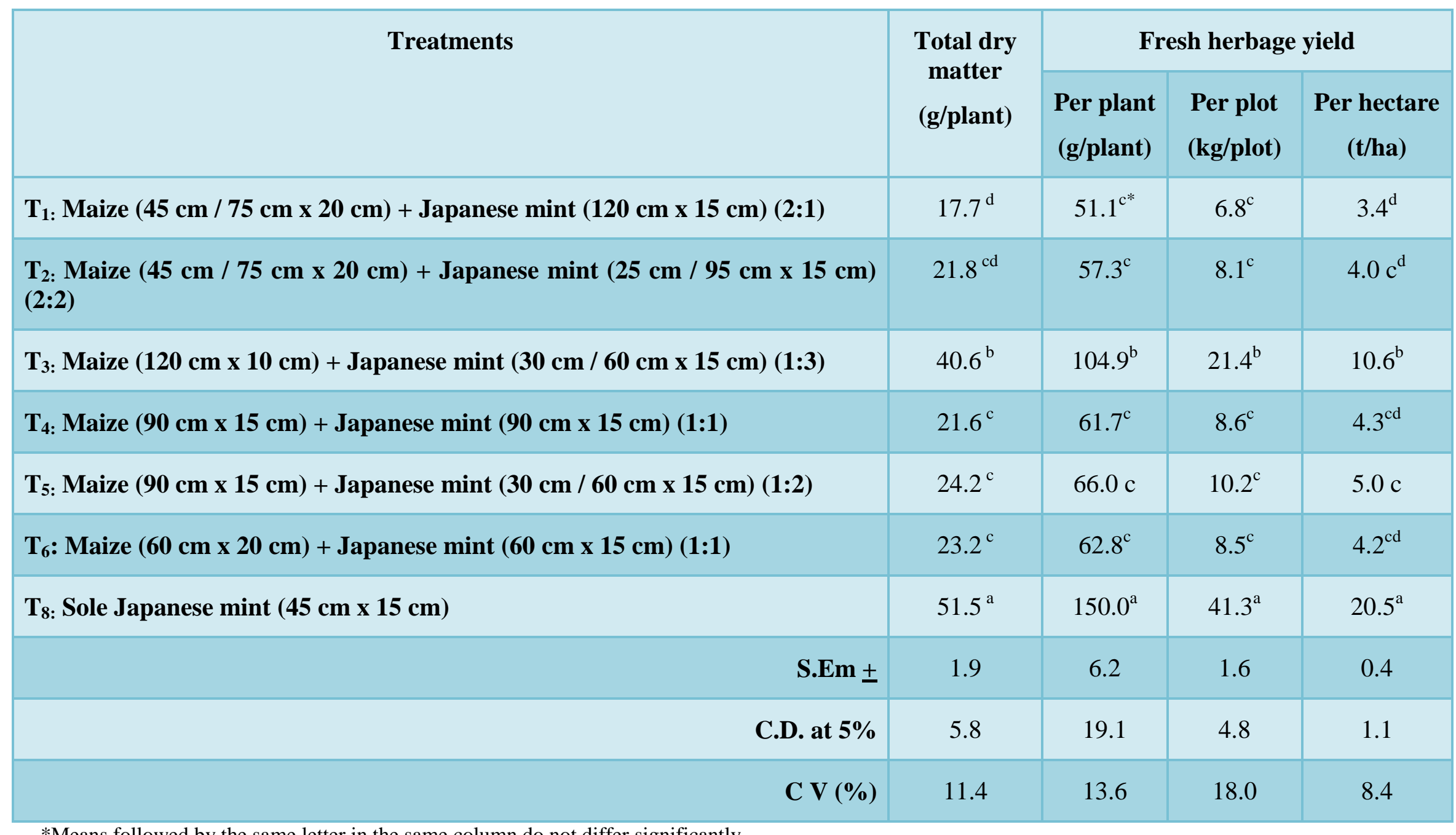

*Means followed by the same letter in the same column do not differ significantly.

Note: $\mathrm{T}_{7}$ : Sole maize $(60 \mathrm{~cm} \mathrm{x} 20 \mathrm{~cm})$ 
Table.4 Oil content, oil yield and menthol content in Japanese mint as influenced by intercropping with maize

\begin{tabular}{|c|c|c|c|c|}
\hline Treatments & $\begin{array}{l}\text { Oil content } \\
(\%)\end{array}$ & $\begin{array}{l}\text { Oil yield } \\
\text { (g/plot) }\end{array}$ & $\begin{array}{c}\text { Oil yield } \\
\text { (Kg/ha) }\end{array}$ & $\begin{array}{c}\text { Menthol } \\
\text { content } \\
(\%)\end{array}$ \\
\hline$T_{1:}$ Maize $(45 \mathrm{~cm} / 75 \mathrm{~cm} \times 20 \mathrm{~cm})+$ Japanese mint $(120 \mathrm{~cm} \times 15 \mathrm{~cm})(2: 1)$ & $0.6^{b^{*}}$ & $29.3^{\mathrm{c}}$ & $14.5^{\mathrm{d}}$ & 64.96 \\
\hline$T_{2:}$ Maize (45 cm / $75 \mathrm{~cm}$ x $\left.20 \mathrm{~cm}\right)+$ Japanese mint $(25 \mathrm{~cm} / 95 \mathrm{~cm}$ x $15 \mathrm{~cm})(2: 2)$ & $0.6^{\mathrm{b}}$ & $42.3^{c}$ & $20.9^{\mathrm{cd}}$ & 65.24 \\
\hline$T_{3:}$ Maize $(120 \mathrm{~cm} \times 10 \mathrm{~cm})$ + Japanese mint $(30 \mathrm{~cm} / 60 \mathrm{~cm} \times 15 \mathrm{~cm})(1: 3)$ & $0.9^{\mathrm{a}}$ & $195.6^{\mathrm{b}}$ & $97.0^{\mathrm{b}}$ & 68.19 \\
\hline$T_{4:}$ Maize $(90 \mathrm{~cm} \times 15 \mathrm{~cm})+$ Japanese mint $(90 \mathrm{~cm} \times 15 \mathrm{~cm})(1: 1)$ & $0.6^{\mathrm{b}}$ & $45.5^{\mathrm{c}}$ & $22.6^{\mathrm{cd}}$ & 65.39 \\
\hline$T_{5:}$ Maize $(90 \mathrm{~cm} \times 15 \mathrm{~cm})+$ Japanese mint $(30 \mathrm{~cm} / 60 \mathrm{~cm}$ x $15 \mathrm{~cm})(1: 2)$ & $0.8^{\mathrm{a}}$ & $66.6^{\mathrm{c}}$ & $33.0^{\mathrm{c}}$ & 67.26 \\
\hline$T_{6}:$ Maize $(60 \mathrm{~cm} \times 20 \mathrm{~cm})+$ Japanese mint $(60 \mathrm{~cm} \times 15 \mathrm{~cm})(1: 1)$ & $0.6^{\mathrm{b}}$ & $46.5^{\mathrm{c}}$ & $23.0^{\mathrm{cd}}$ & 66.93 \\
\hline$T_{8:}$ Sole Japanese mint $(45 \mathrm{~cm} \mathrm{x} 15 \mathrm{~cm})$ & $0.9^{\mathrm{a}}$ & $388.0^{\mathrm{a}}$ & $192.4^{\mathrm{a}}$ & 68.15 \\
\hline $\mathbf{S . E m} \pm$ & 0.05 & 17.5 & 4.5 & 0.9 \\
\hline C.D. at $5 \%$ & 0.2 & 53.8 & 13.8 & NS \\
\hline C V (\%) & 12.6 & 26.0 & 13.4 & 2.2 \\
\hline
\end{tabular}

*Means followed by the same letter in the same column do not differ significantly.

Note: $\mathrm{T}_{7}$ : Sole maize $(60 \mathrm{~cm}$ x $20 \mathrm{~cm}$ 
Table.5 Assessment of yield advantage in intercropping systems efficiency

\begin{tabular}{|c|c|c|c|c|}
\hline Treatments & LER & ATER & $\begin{array}{c}\text { Maize grain } \\
\text { equivalent } \\
\text { yield (q/ha) }\end{array}$ & $\begin{array}{c}\text { Japanese mint } \\
\text { oil equivalent } \\
\text { yield (kg/ha) }\end{array}$ \\
\hline$T_{1:}$ Maize $(45 \mathrm{~cm} / 75 \mathrm{~cm} \times 20 \mathrm{~cm})+$ Japanese mint $(120 \mathrm{~cm} \times 15 \mathrm{~cm})(2: 1)$ & $1.1^{\mathrm{bc} *}$ & $1.0 \mathrm{c}^{\mathrm{d}}$ & $133.0^{\mathrm{d}}$ & $164.6^{\mathrm{d}}$ \\
\hline $\begin{array}{l}\text { T2: Maize }(45 \mathrm{~cm} / 75 \mathrm{~cm} \times 20 \mathrm{~cm})+\text { Japanese mint }(25 \mathrm{~cm} / 95 \mathrm{~cm} \times 15 \\
\mathrm{cm})(2: 2)\end{array}$ & $1.1^{\mathrm{bc}}$ & $1.1^{\mathrm{cd}}$ & $142.2^{\mathrm{cd}}$ & $175.9^{\mathrm{cd}}$ \\
\hline$T_{3:}$ Maize $(120 \mathrm{~cm} \times 10 \mathrm{~cm})+$ Japanese mint $(30 \mathrm{~cm} / 60 \mathrm{~cm} \times 15 \mathrm{~cm})(1: 3)$ & $1.5^{\mathrm{a}}$ & $1.4^{\mathrm{a}}$ & $252.5^{\mathrm{a}}$ & $312.4^{\mathrm{a}}$ \\
\hline$T_{4:}$ Maize $(90 \mathrm{~cm} \times 15 \mathrm{~cm})+$ Japanese mint $(90 \mathrm{~cm} \times 15 \mathrm{~cm})(1: 1)$ & $1.2^{\mathrm{b}}$ & $1.2^{\mathrm{b}}$ & $146.3^{\text {bcd }}$ & $180.9^{\text {bcd }}$ \\
\hline$T_{5:}$ Maize $(90 \mathrm{~cm} \times 15 \mathrm{~cm})+$ Japanese mint $(30 \mathrm{~cm} / 60 \mathrm{~cm} \times 15 \mathrm{~cm})(1: 2)$ & $1.2^{\mathrm{b}}$ & $1.2^{\mathrm{b}}$ & $161.7^{\mathrm{b}}$ & $200.0^{\mathrm{b}}$ \\
\hline$T_{6}:$ Maize $(60 \mathrm{~cm} \times 20 \mathrm{~cm})+$ Japanese mint $(60 \mathrm{~cm} \times 15 \mathrm{~cm})(1: 1)$ & $1.2^{\mathrm{b}}$ & $1.1^{\mathrm{bc}}$ & $147.8^{\text {bcd }}$ & $182.8^{\mathrm{bcd}}$ \\
\hline$T_{7}:$ Sole maize $(60 \mathrm{~cm} \times 20 \mathrm{~cm})$ & $1^{\mathrm{c}}$ & $1^{\mathrm{d}}$ & $135.8^{\mathrm{d}}$ & $168.0^{\mathrm{d}}$ \\
\hline$T_{8:}$ Sole Japanese mint $(45 \mathrm{~cm} \times 15 \mathrm{~cm})$ & $1^{\mathrm{c}}$ & $1^{\mathrm{d}}$ & $155.6^{\mathrm{bc}}$ & $192.4^{\mathrm{bc}}$ \\
\hline $\mathbf{S . E m} \pm$ & 0.02 & 0.02 & 5.6 & 7.0 \\
\hline C.D. at $5 \%$ & 0.2 & 0.1 & 17.2 & 21.2 \\
\hline $\mathrm{CV}(\%)$ & 7.7 & 5.6 & 6.2 & 6.1 \\
\hline
\end{tabular}

*Means followed by the same letter in the same column do not differ significantly

LER: Land equivalent ratio, ATER: Area time equivalent ratio 
Table.6 Economic analysis of maize and Japanese mint intercropping systems

\begin{tabular}{|c|c|c|c|c|}
\hline Treatments & $\begin{array}{c}\text { Cost of } \\
\text { cultivation } \\
\text { (Rs./ha) }\end{array}$ & $\begin{array}{c}\text { Gross } \\
\text { returns } \\
\text { (Rs./ ha) }\end{array}$ & $\begin{array}{c}\text { Net } \\
\text { returns } \\
\text { (Rs./ ha) }\end{array}$ & B:C ratio \\
\hline$T_{1:}$ Maize $(45 \mathrm{~cm} / 75 \mathrm{~cm} \times 20 \mathrm{~cm})+$ Japanese mint $(120 \mathrm{~cm} \times 15 \mathrm{~cm})(2: 1)$ & 53,497 & $1,56,372$ & $1,02,875$ & 2.92 \\
\hline$T_{2:}$ Maize $(45 \mathrm{~cm} / 75 \mathrm{~cm} \times 20 \mathrm{~cm})+$ Japanese mint $(25 \mathrm{~cm} / 95 \mathrm{~cm} \times 15 \mathrm{~cm})(2: 2)$ & 61,553 & $1,67,124$ & $1,05,571$ & 2.71 \\
\hline$T_{3:}$ Maize $(120 \mathrm{~cm} \times 10 \mathrm{~cm})+$ Japanese mint $(30 \mathrm{~cm} / 60 \mathrm{~cm} \times 15 \mathrm{~cm})(1: 3)$ & 76,420 & $2,55,639$ & $1,79,219$ & 3.34 \\
\hline$T_{4:}$ Maize $(90 \mathrm{~cm} \times 15 \mathrm{~cm})+$ Japanese mint $(90 \mathrm{~cm} \times 15 \mathrm{~cm})(1: 1)$ & 57,234 & $1,71,851$ & $1,14,617$ & 3.00 \\
\hline$T_{5:}$ Maize $(90 \mathrm{~cm} \times 15 \mathrm{~cm})+$ Japanese mint $(30 \mathrm{~cm} / 60 \mathrm{~cm}$ x $15 \mathrm{~cm})(1: 2)$ & 63,307 & $1,90,074$ & $1,26,767$ & 3.00 \\
\hline$T_{6}:$ Maize $(60 \mathrm{~cm} \times 20 \mathrm{~cm})+$ Japanese mint $(60 \mathrm{~cm} \times 15 \mathrm{~cm})(1: 1)$ & 61,711 & $1,73,628$ & $1,11,917$ & 2.81 \\
\hline$T_{7}:$ Sole maize $(60 \mathrm{~cm} \times 20 \mathrm{~cm})$ & 43,218 & $1,59,677$ & $1,16,459$ & 3.69 \\
\hline$T_{8:}$ Sole Japanese mint $(45 \mathrm{~cm} \times 15 \mathrm{~cm})$ & 70,366 & $1,82,818$ & $1,12,452$ & 2.59 \\
\hline
\end{tabular}


Fig.1 Net returns (Rs/ha) of different intercropping systems

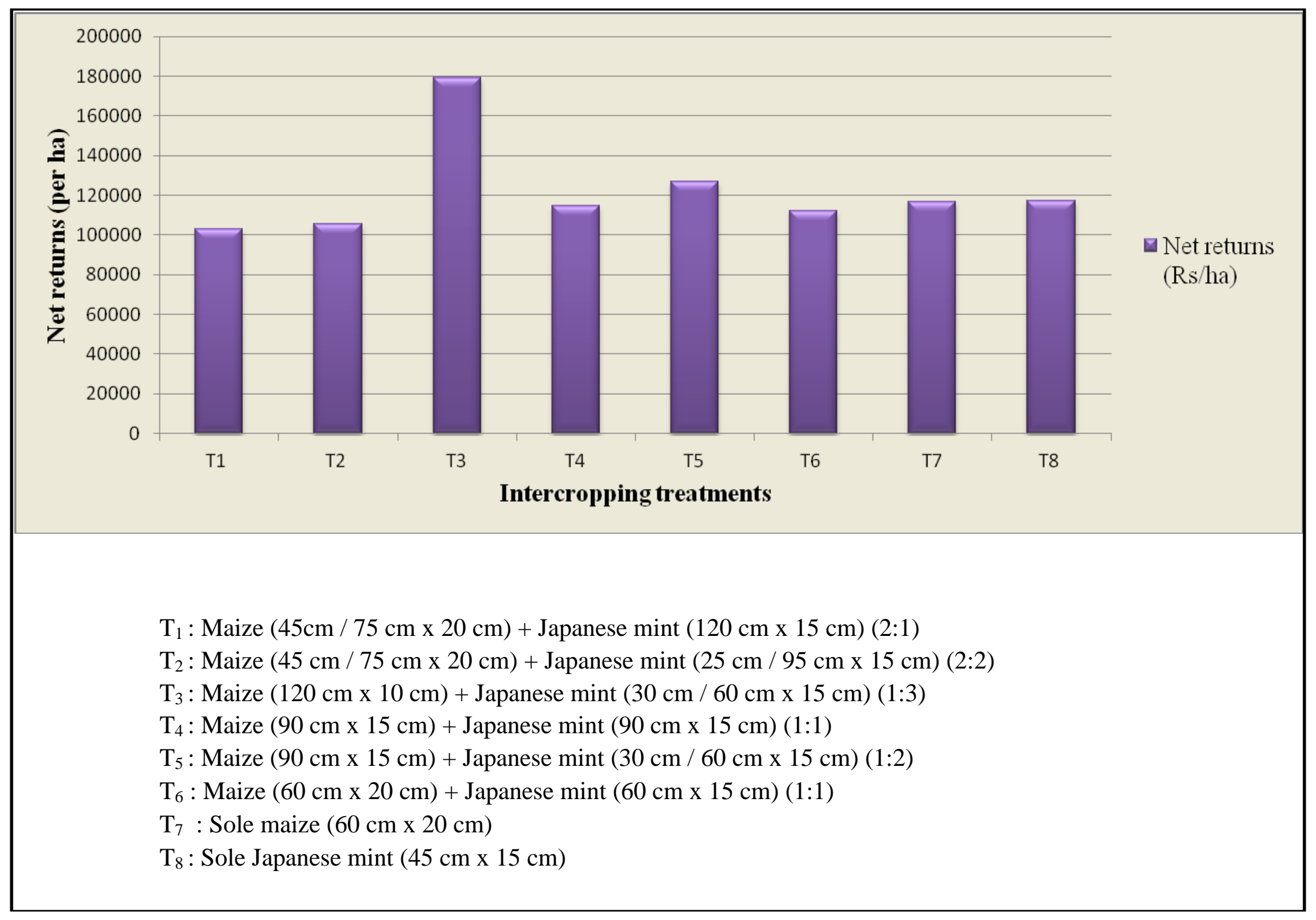


The results of the studies are in line with intercropping of sugarcane with Japanese mint and spear mint (Kothari and Singh, 2004).

\section{Land equivalent ratio (LER)}

The data on LER was greater than unity (1.1 to 1.5) in all the intercropping systems tried. This showed the advantage of intercropping over sole cropping. Among all the row proportion, the highest LER was obtained in 1:3 row proportion $\left(\mathrm{T}_{3}\right)$ (1.5) (Table 5).

In the above intercropping system both the crops expressed their yield potentiality and were found complementary to each other. This advantage was mainly attributed to the maize crop, which produced identical yields in both sole and intercropping systems, whereby the yields of Japanese mint were obtained as bonus yields over and above that of maize in intercropping. Higher LER in intercropping treatments compared to sole cropping was attributed to better utilization of natural resources in addition to inputs used. Similar findings were reported by other investigators in spearmint (Lulie et al., 2014)

\section{Area time equivalent ratio (ATER)}

Area time equivalent ratio (1.1 to 1.4 ) also followed the similar trend as that of LER (Table 8). The $\mathrm{T}_{3}$ (1.4) accommodated additional population of Japanese mint from which a considerable yield was obtained without reduction in the maize yield. This indicates efficient utilization of time in addition to the land. The higher ATER might be attributed to higher yield of mint obtained coupled with shorter duration without affecting the yield of maize. Similarly, results of Rajeshwara Rao et al., (2002) in corn mint and rose scented geranium showed same tendency.

\section{Maize grain equivalent yield (q/ha)}

Intercropping of maize with mint in 1:3 row proportion $\left(\mathrm{T}_{3}\right)$ reported maximum maize equivalent yield $(252.5 \mathrm{q} / \mathrm{ha})$ compared to other intercropping combinations. The higher maize equivalent yield in $T_{3}$ was due to higher yield and higher market price of both the component crops. Similarly, Yogesh et al., (2014) reported higher maize equivalent yield in soyabean intercropping

\section{Japanese mint oil equivalent yield (kg/ha)}

The maximum Japanese mint equivalent oil yield $\left(312.4 \mathrm{~kg} / \mathrm{ha}\right.$ ) was recorded in $\mathrm{T}_{3}$ when compared to all other intercropping systems and also sole cropping treatments (Table 5). Though the yield of Japanese mint decreased in intercropping treatments as compared to sole cropping treatments, the comparative performance of both Japanese mint and identical yield of maize in intercropping treatments has resulted in higher productivity of the system. Higher yield and high market price of both the component crops increased the mint equivalent oil yield. The results are in agreement with the findings of Gill et al., (2007) in Japanese mint intercropping with onion, maize and oilseed rape.

\section{Economics of intercropping systems}

Among the intercropping combinations higher gross (Rs. 2, 55,639/ ha) and net returns (Rs. 1,79,219/ha) and $\mathrm{B}$ : $\mathrm{C}$ ratio (3.34) was obtained from $\mathrm{T}_{3}$ (maize $(120 \mathrm{~cm} \times 10 \mathrm{~cm})+$ Japanese mint $(30 \mathrm{~cm} / 60 \mathrm{~cm} \times 15 \mathrm{~cm})$, in $1: 3$ row proportions (Table $6 \&$ Fig. 1)). This was because of the highest production of essential oil by Japanese mint in an intercropping system and better performance of maize in intercropping similar to sole maize. Higher gross and net return was due to maximum equivalent yield of maize and Japanese mint obtained under intercropping system. Singh 
and Shivaraj (1998) also obtained higher net returns when palmarosa was intercropped with pigeonpea.

In conclusion, Japanese mint as an intercrop with maize performed better without affecting the growth and yield of maize. The intercropping of maize $(120 \mathrm{~cm} \mathrm{x} 10 \mathrm{~cm})+$ Japanese mint $(30 \mathrm{~cm} / 60 \mathrm{~cm} \times 15 \mathrm{~cm})$ in $1: 3$ row proportions $\left(\mathrm{T}_{3}\right)$ was found suitable to increase the productivity, land use efficiency and to get higher net income from unit area and to utilize the resources efficiently. Thus, this study found that it was possible to grow Japanese mint as intercrop with maize under irrigated condition without affecting the traditional crop maize.

\section{References}

Chandranath, H. T. and Pujari, B. T., 2011, Feasibility of companion cropping of sunflower (Helianthus annuus) and ashwagandha (Withania somnifera Dunal) with various rows ratio and seed rates under rainfed condition. Internat. J. agric. Sci., 7(1): 42-46.

Evans, J., Mcneill, A. M., Unkovich, M. J., Fettell, N. A., Heenan, D. P., 2001, Net nitrogen balances for cool-season grain legume intercropping and contributions to wheat nitrogen uptake: a review. Aus. J. Exp. Agric., 41: 347-359.

Gill, B. S., Gill, G. S. and Salaria, A., 2007, Intercropping Japanese mint (Mentha arvensis L.) with maize, oilseed rape and onion during rabi season. $J$. Spices Aromatic Crops, 16(1): 27-30.

Hiebsch, C. K. and Macollam, R. E., 1980, Area time equivalency ratio. A method for evaluating the productivity of intercrops. Agronomy J., 79: 15-22.

Kothari, S. K. and Singh, U. B., 2004, Intercropping of Menthol Mint (Mentha arvensis L.) and Spearmint
(Mentha spicata L.) with sugarcane (Saccharum officinarum). J. Spices Aromatic Crops, 13(2): 110-116.

Lulie, B., Getu, H. and Bogale, T., 2014, Intercropping of Maize (Zea mays L.) with Spear mint (Mentha spicata L.) as supplementary income generation at Wondo Genet Agricultural Research Center, South Ethiopia. J. Rec. Res. Life Sci., 1(1): 31-43.

Prakasa Rao, E. V. S., Singh, M. and Ganesh Rao, R. S., 1988, Intercropping studies in Java citronella. Field Crops Res., 18: 279-286.

Rajeshwara Rao, B. R., 2002, Biomass yield, essential oil yield and essential oil composition of rose-scented geranium (Pelargonium species) as influenced by row spacing and intercropping with cornmint (Mentha arvensis L. f. piperascens Malinv. ex Holmes). Ind. Crops Prod., 16: 133 - 144.

Singh, S. M. and Shivaraj, B., 1998, Intercropping Studies in lemongrass (Cymbopogon flexuosus). J. Agron. crop sci., 180(1): 23-26.

Singh, U. B., 1998. Studies on resource utilization and productivity maximization of autumn planted sugarcane-mint intercrop system in Central Uttar Pradesh. Ph.D. thesis, submitted to Dr Ambedkar University, Agra, India.

Willey, R. W., 1979, Intercropping: its importance and research needs: Part I. Competition and yield advantages. Field Crop Abst., 32: 1103.

Yogesh, S., Halikatti, S. I., Hiremath, S. M., Potdar, M. P., Harlapur, S. I. and Venkatesh, H., 2014, Light use efficiency, productivity and profitability of maize and soybean intercropping as influenced by planting geometry and row proportion. Karnataka J. Agric. Sci., 27(1): 1-4. 


\section{How to cite this article:}

Suparna Nayak, Anand B. Mastiholi, T. N. Pushpa and Srikantaprasad, D. 2020. Studies on Japanese Mint (Mentha arvensis L.) and Maize (Zea mays L.) Intercropping System under Irrigated Condition. Int.J.Curr.Microbiol.App.Sci. 9(07): 1428-1441. doi: https://doi.org/10.20546/ijcmas.2020.907.164 